\title{
Corporate Social Responsibility during the Coronavirus Pandemic: An Interim Overview
}

\author{
Shaike Marom (Corresponding author) \\ Professor of Management, School of Management, Kinneret College, Israel \\ E-mail: shaike.marom@gmail.com
}

Robert N. Lussier

Professor of Management Emeritus, Springfield College, USA

CEO Publish Do Not Perish, www.publishdonotperish.com

Tel: 413-224-1145 E-mail: rlussier@springfield.edu

Received: April 23, 2020 Accepted: May 10, 2020 Published: May 17, 2020

doi:10.5296/ber.v10i2.17046ＵRL: https://doi.org/10.5296/ber.v10i2.17046

\begin{abstract}
The Coronavirus outbreak caught the world by surprise, spreading like wildfire and causing fatal illness to many. The ongoing pandemic and its implications have led to severe global socioeconomic disruption, halting most regular activities. Coping with the pandemic and its horrible consequences required to pull together all resources and unite efforts by individuals, organizations and governments. Businesses have embarked on an effort to support coping with the pandemic in various ways, as aligned with the concept of corporate social responsibility (CSR). The article reviews the various ongoing CSR efforts in the fight against the Coronavirus pandemic, serving better understanding on best CSR practices at times of crisis and in the afterwards 'new normal'.
\end{abstract}

Keywords: Corporate social responsibility, Coronavirus, Stakeholders, Core competencies

\section{Introduction}

The coronavirus outbreak, which started in China in December 2019, was spreading rapidly worldwide and was declared pandemic by the World Health Organization (WHO) in March of 2020. As of 15 April 2020, around 2 million cases have been reported resulting in more than 120,000 deaths (\#152, \#153). The outbreak of the Coronavirus caused global socioeconomic disruption including the shutdown of factories and businesses, halting transportation, postponement of events, travel restrictions, social distancing and lockdown 
(\#154). The International Monetary Fund predicted global GDP will shrink 3\% in 2020, marking the worst economic contraction since the Great Depression almost a century ago (IMF, 2020). Additionally, the sudden increase in number of patients needing hospital treatment coupled with shortage in medical supplies and equipment, resulted in overflow beyond the maximum capacity of the healthcare system (\#155, \#156). Organizations and businesses have embarked on an effort to support fighting the pandemic in various ways, providing products, manufacturing capabilities and logistic support, community services and funding volunteering programs. This article provides an interim review of the various corporate social responsibility (CSR) practices in the fight against the coronavirus pandemic. It provides extensive data about CSR practices through two main perspectives - according to target stakeholders constituencies and according to various dimensions of firms' core competencies. This leads to better understanding on which CSR best practices in terms of the business and society, as well as serving as a basis for further research examining various aspects of CSR at times of crisis and in the afterwards 'new normal'.

\section{Literature Review - Corporate Social Responsibility}

A brief literature review on corporate social responsibility (CSR), is provided as a background to the follow-on overview of Coronavirus-related activities within the CSR domain.

In recent years, the pursuance of CSR has gained wide recognition as a good practice that can lead to improved corporate image and financial performance. The concept is not new and is based on the belief that "companies have some responsibilities to society beyond that of making profits for the shareholders." (Carroll \& Shabana, 2010). The premise of CSR is that corporations have moral responsibilities that go beyond simply making profit for their owners and shareholders (Berman, Wicks, Kotha \& Jones, 1999). Being socially responsible means going beyond legal and economic obligations to do the right things by acting in ways that benefit society (Farooq, Rupp \& Farooq, 2017). CSR is about doing good and doing no harm (Pearce, Wassenaar \& Manz, 2017) and relationships with stakeholders (Washburn \& Bromiley, 2013). When Google started, it had the motto, "Don't be evil." Thus, CSR has been defined as "the voluntary actions that business can take, over and above compliance with minimum legal requirements, to address both its own competitive interests and the interests of wider society" (Timperley, 2008).

\subsection{The Development of CSR}

Since the mid- $20^{\text {th }}$ century, the definition of CSR has evolved from normative and ethics-oriented arguments, through integrative approach, to instrumental and performance-oriented focus (Carroll, 1999; Lee, 2008). The normative view is based on a perspective claiming that corporations, above any other consideration, ought to undertake social responsibilities as an ethical obligation to the society by large. The integrative approach argues that businesses depend on society, including input resources from, and output products to society; for their existence and growth (Garriga \& Melé, 2004). Manifesting this view, Eells \& Walton (1974) asserted that: 
Insofar as the business system as it exists today can only survive in an effectively functioning free society, the corporate social responsibility movement represents a broad concern with business's role in supporting and improving that social order (1974:247).

By the instrumental perspective, CSR means that corporations are expected to achieve profits and financial stability, a concept rooted in the assumption that the role of corporation is wealth creation for the benefit of society at large (Donaldson \& Preston, 1995; Garriga \& Melé, 2004). The salience of the financial aspect of CSR is reflected in the work of Carroll, who asserted that "the social responsibility of business encompasses the economic, legal, ethical, and discretionary expectations that society has of organizations at a given point of time," and went on to portray those aspects as four layers of the pyramid of CSR (1979: 500). By the pyramid metaphor, Carroll suggests that each CSR element is a prerequisite for the one built upon it. Accordingly, the economic responsibility of the firm, which forms the first layer, is necessary because without it, the firm would not survive as an entity that contributes to society.

\subsection{Benefits and Costs of CSR}

There is debate on the question of how CSR affects corporate financial and economic performance (Hafenbradl \& Waeger, 2017). With so many factors affecting profits, how do you measure only CSR contribution to profits? Significant body of research examined the relationship between CSR and corporate financial performance (CFP) (Griffin \& Mahon, 1997; Orlitzky et al., 2003, Marom, 2006). Although the results of these studies were not conclusive (McWilliams \& Siegel, 2001; Roman, Hayibor \& Agle, 1999; Rowley \& Berman, 2000), the majority concluded that there is a positive relationship between CSR and CFPs (Griffin \& Mahon, 1997; Orlitzky et al., 2003). This led to the notion that a firm's socially responsible conduct would advance its competitive advantage and result in better financial performance and sustainability. Consequently, CSR developed to be an element of business strategy, aiming to develop a competitive advantage (Lantos, 2002; Porter \& Kramer, 2006). In other words, those corporations engaged in CSR will, with all things being equal, be more financially successful.

If CRS didn't benefit the company in some way, why would virtually all U.S. large public corporations have CSR programs (Nalick, Josefy, Zardkoohi \& Bierman, 2016)? Several companies with reputations for good CSR have much larger profits than those that have poor reputations (Derousseau, 2018). Companies considered to be highly socially responsible by Forbes, "The Just 100: America's Best Corporate Citizens, had an average return of $13.6 \%$ compared to $9.9 \%$ for those that have lower ratings of CSR (Schaefer, 2016). With a choice of two products of similar price and quality, $80 \%$ of surveyed customers said they are willing to buy the more sustainable option (Master Class, 2013).

Although companies can benefit from CSR, there are often upfront cost before getting a payback on the investment. There are also cost for the lack of CSR to a business. CSR has been in the news constantly for the past several years (Manz, 2015). Being socially irresponsible has negative consequences, as it gives the company a negative reputation that 
leads to more difficulty in attracting customers, investors, and employees, and it can lead to costly lawsuits. Money can be made again, but a negative reputation can take years to improve, and a good reputation may be lost forever (Cohen, 2012).

\subsection{Stakeholder and CSR}

The stakeholder theory of the firm is strongly related to the practical application of CSR. It asserts that multiple constituencies - stakeholders, should be considered when managing a firm, and not just shareholders. There have been numerous definitions of stakeholder. The classic definition by Freeman (1984) identifies a stakeholder group as one that "can affect or is affected by the achievement of the organization's objectives". Under such definition multiple constituencies could be considered including employees, customers, suppliers, investors, communities and others.

The organization can affect stakeholders negatively as well as positively. Stakeholders can be harmed by the firms' actions as well as be helped to achieve their goals. Conversely, stakeholders can act in ways that either help or hinder the firm achieve its goals (Rowley \& Berman, 2000). Firms therefore institute stakeholder management practices in order to address the needs and expectations of their stakeholders to avoid negative outcomes and induce positive outcomes for themselves (Donaldson \& Preston, 1995; Freeman, 1984).

Currently, almost every major corporation has explicitly adopted nonfinancial CSR goals as part of their mission, and diversity has become particularly important because of its benefits to both business and society (Schubert \& Tavassoli). In 2019, the Business Roundtable 181 CEO of major corporations issued a statement saying that they "share a fundamental commitment to all of our stakeholders." Members embraced a model of capitalism that takes into account the interest of all corporate stakeholders - and therefor renounced the idea that stockholders should always come first (Wartzman \& Tang, 2019).

\section{Coronavirus Related CSR - Stakeholder Dimensions}

This section provides an overview of CSR activities, in relation to the situation caused by the coronavirus outbreak, examined through the prism of various stakeholder groups. Pressure to maintain profits in an uncertain business environment is driving executives to seek competitive advantages (Sen, Kotlarsky \& Budhwar, 2020).

\subsection{Employees}

Employees are the most valuable organizational resource, and how the firm treats its employees is related to its performance (Raffiee \& Byun, 2020). Corporate social responsibility toward employees may include multiple aspects such as job security, fair remuneration and compensation, health and safety, suitable working conditions, organizational justice, avoid discrimination-diversity and inclusion, labor relations and collective bargaining, flexible work arrangements, training and career path, and more (Crane \& Matten, 2004; Panapanaan et al., 2003; Remisova et al., 2013).

Some of these aspects are more significant in relation to the situation caused by the coronavirus outbreak. For example, it goes without saying that job security, compensation 
and health and safety are highly important in this context. An overview of some of these aspects, with some example companies that followed this practice, is provided in the following table 1 .

Table 1. CSR Dimensions - Stakeholders - Employees

\begin{tabular}{|l|l|}
\hline Companies & Details \\
\hline Amazon, Starbucks, & Paid time off / paid Leave (full or limited) \\
\hline $\begin{array}{l}\text { Lowe's, Walmart, Target, Marriott, } \\
\text { Disney World, Tesla, Macy's, } \\
\text { Everlane, Sonder, Nissan, Honda, }\end{array}$ & $\begin{array}{l}\text { Furlough - Keep the job open (Limited period, } \\
\text { Partially), Waive attendance policy for a certain } \\
\text { period (Limited period), Quarantine pay, }\end{array}$ \\
\hline $\begin{array}{l}\text { Facebook, Google, Microsoft, Apple, } \\
\text { Twitter, Amazon, CISCO, Coca-Cola, }\end{array}$ & Work from home, Flextime, Telecommuting \\
\hline $\begin{array}{l}\text { Walmart, Trader Joe's, Apple, Amazon, } \\
\text { Instacart, DoorDash, McDonald's, } \\
\text { Burger King, Kroger, etc. }\end{array}$ & Paid sick leave (various periods) \\
\hline Multiple businesses: Coca-Cola, & Keeping employees safe, Protecting measures \\
\hline Target, Uber, Whole Foods, & Support services such as financial assistance, \\
\hline Media Reference List: \#102,\#116, \#121, \#124,\#125, \#137, \\
\hline
\end{tabular}

\subsection{Customers}

Corporate social responsibility toward customers may include multiple aspects such as product quality, safety and environment friendly, fair price, quality of service throughout product life cycle, honest and truthful advertising, and more (Crane \& Matten, 2004). This perception is also in line with the marketing concept of customer perceived value (CPV) which explains why customers will prefer one product over the other, and includes, among others, the elements of product benefits, service benefits, monetary costs and time and energy cost (Kotler \& Keller, 2012).

Some of these aspects are more significant in relation to the situation caused by the coronavirus outbreak. For example, online services, deferred payments due to financial difficulties, home delivery are some of the more important issues in this context. An overview of some of these aspects, with some example companies that followed this practice, is provided in the following tables 2 and 3. 
Table 2. CSR Dimensions - Stakeholders - Customers

\begin{tabular}{|c|c|}
\hline Companies & Details \\
\hline $\begin{array}{l}\text { Financial institutions: Citi, PNC, Key Bank, } \\
\text { JPMorgan Chase, Bank of America, etc. }\end{array}$ & $\begin{array}{l}\text { Defer payments of loans, mortgage, } \\
\text { waivers of monthly service fees, etc. }\end{array}$ \\
\hline Multiple companies & Online services \\
\hline Food businesses: Postmates, Instacart, etc. & $\begin{array}{l}\text { Home delivery, Leave at my door } \\
\text { delivery option, }\end{array}$ \\
\hline Travel Companies: Airbnb, Expedia, Hilton, etc. & No cancellation fee \\
\hline $\begin{array}{l}\text { Retail businesses: Walmart, Costco, Target, } \\
\text { Whole Foods, Dollar General, Publix, Giant, }\end{array}$ & Special operating hours for elderly \\
\hline Online businesses: Amazon, Walmart, eBay, & Prevent price gouging for necessary items \\
\hline
\end{tabular}

More specific examples on creating customer value through deals, discounts and freebies, relate to the coronavirus outbreak are listed below in table 3 .

Table 3. CSR Dimensions - Stakeholders - Customers - Deals, Discounts and Freebies

\begin{tabular}{|l|l|}
\hline Companies & Details \\
\hline Food: Starbucks, KFC, Uber Eats, & Freebies, home delivery, etc. \\
\hline Entertainment: HBO, SiriusXM, Amazon, & Free programs, Music, Digital Books \\
\hline $\begin{array}{l}\text { Fitness: Peleton, Nike Training Club, } \\
\text { Planet Fitness, }\end{array}$ & Free virtual fitness classes, \\
\hline $\begin{array}{l}\text { Service Providers: AT\&T, Sprint, } \\
\text { T-Mobile, Comcast (Xfinity), }\end{array}$ & $\begin{array}{l}\text { Increased usage capacity, free use } \\
\text { of WiFi network, }\end{array}$ \\
\hline Other: U-Haul & 30 days of free self-storage to students \\
\hline Media Sources List: \#102,\#103,\#104,\#122, \\
\hline
\end{tabular}

\subsection{Community}

Corporate social responsibility toward communities may include multiple aspects such as

charitable giving to the community, in-kind giving of a firm's products and services that are in need, or the use of facilities or managerial expertise, helping those in need, and more (Crane \& Matten, 2004; Darus et al., 2014). Some of these aspects are more significant in relation to the situation caused by the coronavirus outbreak. For example, medical and food products are highly important in this context. An overview of some of these aspects, with some example companies that followed this practice, is provided in the following table 4. 
Table 4. CSR Dimensions - Stakeholders - Community

\begin{tabular}{|l|l|}
\hline Companies & Details \\
\hline MGM Resorts & $\begin{array}{l}\text { Donated } 480,000 \text { pounds of food to food banks } \\
\text { and communities across the US }\end{array}$ \\
\hline PepsiCo & $\begin{array}{l}\text { Donated and funded medical needs and food (50 million meals) } \\
\text { to at-risk populations, }\end{array}$ \\
\hline WeeCare & Assisting families in finding a temporary childcare solution \\
\hline Nestlé & donating food, medical nutrition products, bottled water, and more \\
\hline Coca-Cola & community relief programs, medical supplies \\
\hline Alice + Olivia & donating masks, \\
\hline The Home Depot & $\begin{array}{l}\text { donated its entire stock of N95 masks to hospitals, first } \\
\text { responders and other healthcare providers }\end{array}$ \\
\hline \multicolumn{2}{|l}{ Media Sources List: \#135,\#136, \#137,\#138,\#139, } \\
\hline
\end{tabular}

\subsection{Shareholders}

Some say the reason that the Business Roundtable major U.S. corporations are talking up stakeholder capitalism is to fend off growing criticism of its place in society. Shareholder return will continue to be the No.1 concern. Corporations are paying attention to CSR to stakeholders because it is an essential part of making money for shareholders in the long run. The Roundtable vision does not involve shareholders giving up anything to benefit other stakeholder unless it benefits in some way, such as increases brand, reputation, or productivity (Mackintosh, 2020).

Businesses have a fiduciary responsibility to work in the best interest of shareholders, and capitalism is based on for-profit business. Without profits a corporation cannot stay in business and provide a return on shareholder investments, pay taxes to help society, pay employees and increase compensation, give donations to non-profit organizations, and be socially responsible to other stakeholders. But the coronavirus is creating challenges to the status quo on profits, with many businesses currently trying to maintain revenues and to cut cost due to the loss of sales and revenues resulting from the pandemic. Unfortunately, many companies had major layoffs creating a record number of people applying for unemployment.

Other aspects significant in relation to the situation caused by the coronavirus outbreak, specifically related to shareholder meeting and Profit Warning. Due to policies of stay-at-home and social distancing companies had to turn to online virtual shareholder meetings or hybrid in-person/virtual meetings. It should be noticed that in the U.S. there are typically 4,500 shareholder meetings between April and June. Thus, the Securities and Exchange Commission (SEC) has issued guidance for companies to assist with holding annual shareholder meetings virtually (\#142, \#143). An overview of these aspects, with some example companies that followed this practice, is provided in the following table 5. 
Table 5. CSR Dimensions - Stakeholders - Shareholders

\begin{tabular}{|l|l|}
\hline Companies & Details \\
\hline $\begin{array}{l}\text { More than } 900 \text { Companies as off April 12, 2020. Examples: } \\
\text { Citigroup, Bank of America, Levi Strauss \& Co., Howard Hughes, } \\
\text { Berkshire Hathaway, Starbucks, }\end{array}$ & $\begin{array}{l}\text { Inform about/host } \\
\text { virtual or Hybrid } \\
\text { shareholder meetings }\end{array}$ \\
\hline $\begin{array}{l}\text { Multiple Companies (300+). Examples: Microsoft, Boeing, Apple, } \\
\text { Mastercard, Royal Caribbean Cruises, United Airlines, Twitter, Ford, }\end{array}$ & \\
Carnival, Caterpillar, Coca-Cola, Colgate-Palmolive, Costco, Delta & \\
Air Lines, Disney, Expedia, FedEx, GE, HP, Hilton. & \\
\hline Media Sources List: \#140,\#141, \#144,\#145, \\
\hline
\end{tabular}

\subsection{The Environment}

Including sustainability in managing the business is being socially responsible. Today, the world is confronting a colossal unmet need unlike anything in the past, as the warming of or our planet is causing dramatic changes to the climate to the point of being called a crisis (O'Keefe, 2020). A recent World Economic Forum report says that two-thirds of the world population could be living in water-stressed countries by 2025 if current consumption patterns continue (\# 157). One study projects average global income will fall $23 \%$ by the end of the century due to climate change (O'Keefe, 2020). According to a global scientific consensus, the single largest threat to the health of our planet in the decades to come is climate change (The Sustainability Consortium, 2020).

With the pandemic, the environment is the "big winner" of the new situation that was imposed due to the coronavirus outbreak. Satellite picture and data, as well as other environment monitoring facilities, reveal significant decrease in air pollution and $\mathrm{CO} 2$, during the pandemic spread by the new coronavirus (\#150,\#151). This is the result of halting major activities worldwide including industry and transportation. Of course, this has nothing to do with CSR but rather an outcome of the situation. Thus, no specific CSR efforts have been directed to the environment.

\section{Coronavirus Related CSR - Core Competencies Prism}

A different perspective in examining Coronavirus-related CSR is utilized in this section - the core competencies dimension. According to the resource-based view (Barney, 1991) corporations must develop and maintain core competencies that are unique to the firm, and thus leverage on them to create competitive advantage. Such core competencies can exist in every section of the firm's value chain including logistics, operations - production and manufacturing, procurement, research and development, human resource management, marketing and sales and services. While firms are devising their socially responsible output, they will naturally use their core competencies in order to maximize CSR output with optimal expenditure. CSR that is aligned with the core competencies yields high CSR performance as well as further strengthen the core competencies. 


\section{Macrothink}

\subsection{Companies Leveraging Manufacturing Capability for CSR}

Brands that have offered production lines, production capabilities and material resources, to produce and assemble the items needed to treat and contain the coronavirus. Such items include medical equipment such as sanitizers, masks and ventilators. As those are not their typical product, companies are retooling to produce, and switch output the newly needed products. Other companies offering to lend floor space, machinery, staff and production expertise. Some typical activities with some example companies that followed this practice, is provided in the following table 6 .

Table 6. Leveraging Core Competencies - Manufacturing Capability

\begin{tabular}{|l|l|}
\hline \multicolumn{1}{|c|}{ Companies } & \multicolumn{1}{c|}{ Details } \\
\hline Ford, GM, 3M, GE, Tesla, Fiat & $\begin{array}{l}\text { production of respirators for healthcare workers, } \\
\text { ventilators for coronavirus patients, transparent face } \\
\text { shields }\end{array}$ \\
\hline $\begin{array}{l}\text { Deeside Distillery, Verdant Spirits, } \\
\text { LVMH (Louis Vuitton), BrewDog }\end{array}$ & production of the antiviral gel, Hand sanitizers \\
\hline HP (worldwide), Boeing, & $\begin{array}{l}\text { 3D-printed parts to hospitals, Face shields and mask, } \\
\text { Field Ventilator parts, Hands-Free Door Opener }\end{array}$ \\
\hline Dyson, & Developed and making ventilators \\
\hline Media Sources List \#101, \#105,\#106, \#108, \#117,\#122, \#138, \\
\hline
\end{tabular}

\subsection{Companies Leveraging Increase in Production for CSR}

Companies who regularly produce products that are needed in fighting the coronavirus, such as sanitizers, masks and ventilators; are now facing a sharp increase in demand. Thus, those companies are called upon to ramp up production of their own products, while changing production portfolios. Such change calls for high level of flexibility in production arrangements and sharpens the firm capability to do so in the future when conditions in the external environment are changing. Some typical activities with some example companies that followed this practice, is provided in the following table 7. 
Table 7. CSR Dimensions: Leveraging Core Competencies - Ramp up production

\begin{tabular}{|l|l|}
\hline Companies & Details \\
\hline Philips & Ventilators \\
\hline $3 \mathrm{M}$ & Doubled production of N95 masks \\
\hline Abbott, Roche, Qiagen, & Rapid testing device \\
\hline Enercon Technologies & Instruments for diagnostic medical devices \\
\hline Baker & Safety cabinets for coronavirus testing \\
\hline Oskaloosa & Ventilator Parts \\
\hline $\begin{array}{l}\text { Chemical Industries: INEOS, Dow, } \\
\text { DuPont, Henkel, Arkema, etc. }\end{array}$ & $\begin{array}{l}\text { Increase production of required chemicals and } \\
\text { other components to meet growing demand }\end{array}$ \\
\hline Welch Allyn & Medical and critical care products \\
\hline Procter \& Gamble & produce 45,000 liters of hand sanitizer weekly \\
\hline Nordstrom (with partners) & Sew more than 100,000 masks \\
\hline STARC Systems & Containment units for hospitals \\
\hline Media Sources List: \#111, \#112,\#113, \#114,\#115, \#127, \#128, \#129, \#136, \\
\hline
\end{tabular}

\subsection{Companies Leveraging Research and Development for CSR}

Fighting the coronavirus pandemic requires fast development of medical products including diagnostics and treatment capabilities as well as vaccines. This requires investing extreme efforts in research and development mainly from companies in the medical and healthcare industry. Large corporations as well as small start-up firms, are rising to the challenge. Some typical activities with some example companies that followed this practice, is provided in the following table 8 .

Table 8. CSR Dimensions: Leveraging Core Competencies - Research \& Development

\begin{tabular}{|l|l|}
\hline Companies & Details \\
\hline Amgen, CalciMedica, CytoDyn, Gilead Sciences, Regeneron, Roche, & $\begin{array}{l}\text { Treatments } \\
\text { development }\end{array}$ \\
\hline $\begin{array}{l}\text { Johnson \&akeda, Vir Biotech, AstraZeneca, Eli Lilly, Novartis, Pfizer, } \\
\text { BioNTech, Novavon, GSK, Sanofi, Moderna, Heat Biologics, Inovio, } \\
\text { Medicago, OyaGen, Pfizer, }\end{array}$ & $\begin{array}{l}\text { Vaccines } \\
\text { development }\end{array}$ \\
\hline AstraZeneca, Bayer, Novo Nordisk, Roche, Shionogi, Takeda, Abbott, & $\begin{array}{l}\text { Diagnostics } \\
\text { development }\end{array}$ \\
\hline Media Sources List: \#107, \#109,\#110,\#122, & \\
\hline
\end{tabular}

\subsection{Companies Leveraging Information Technology for CSR}

Technology and IT companies are working to provide solutions to fight coronavirus. One such area is the development of application of location tracking technology to help contain the spread of the disease. Other efforts are directed to improve internet availability, and yet 
another focuses on preventing the spread of misinformation. Some typical activities with some example companies that followed this practice, is provided in the following table 9.

Table 9. CSR Dimensions: Leveraging Core Competencies - Information Technology

\begin{tabular}{|l|l|}
\hline Companies & Details \\
\hline Facebook, Apple, Google, & Curtail the spread of coronavirus misinformation \\
\hline Google, Microsoft, & Information on the illness, information tracker, \\
\hline Apple and Google in partnership & $\begin{array}{l}\text { Tracing system to help curb the spread of the virus } \\
\text { by urging users to quarantine or isolate themselves } \\
\text { after contact with an infected individual }\end{array}$ \\
\hline IBM & $\begin{array}{l}\text { using its supercomputing power to help } \\
\text { scientists doing research on COVID-19 }\end{array}$ \\
\hline $\begin{array}{l}\text { Netflix, YouTube, Amazon (Prime } \\
\text { video), Google, Apple (TV), }\end{array}$ & $\begin{array}{l}\text { Reduce internet traffic (reduce streaming } \\
\text { quality) to conserve internet resources }\end{array}$ \\
\hline Google, Apple, Tata & tracing technology to help contain its spread \\
\hline Media Sources List: \#116, \#117,\#119, \#120,\#122, \#136, \#146, \#158 \\
\hline
\end{tabular}

\subsection{Companies Leveraging Logistics Capabilities for CSR}

Shortage of essential supplies including health and medical supplies as well as food in supermarkets, has resulted from the disruption in the global supply chain. The disruption erupted due to production stoppages in many locations and countries, transportation barriers worldwide and shortage in supply-chain workers. Thus, the ability to deliver essential items has been compromised. Companies with strong logistical capabilities and supply chain management have joined in to assist. Some typical activities with some example companies that followed this practice, is provided in the following table 10.

Table 10. CSR Dimensions: Leveraging Core Competencies - Logistics

\begin{tabular}{|l|l|}
\hline Companies & Details \\
\hline Amazon & prioritized medical shipments \\
\hline Apple & $\begin{array}{l}\text { source necessary supplies that are needed for healthcare } \\
\text { workers }\end{array}$ \\
\hline H\&M Procurement, & $\begin{array}{l}\text { use its global supply network to source protective } \\
\text { equipment for hospitals }\end{array}$ \\
\hline Scoutbee, & Free tool for organizations helping identify suppliers \\
\hline $\begin{array}{l}\text { Enabling } \\
\text { Sourcing Allies, ICL, }\end{array}$ & $\begin{array}{l}\text { provided logistics and supply chain support to a } \\
\text { not-for-profit, to help produce face shields }\end{array}$ \\
\hline Coca-Cola & \\
\hline Media Sources List: \#117, \#130,\#131,\#133,\#134, \#136, \#147, \#148, \#149, \\
\hline
\end{tabular}




\section{Limitations and Future Research}

Although this study collected and reviewed significant amount of media information, we acknowledge that it has certain limitations. First, the crisis of the coronavirus pandemic is not yet over at the time this review was conducted. Although there are signs that several countries worldwide, and states in the U.S., have managed to 'flatten the curve' suppressing the spread of the virus, it will take more time until life will be back to a 'new normal'. Thus, the review is a 'snapshot' of the situation at a certain point in time, while the event is not over yet. A second limitation arises out of the fact that the review of CSR practices covers a wide selection of stakeholder constituencies and firms' core competencies, but not all. Thus, additional components of those dimensions can be explored.

Future research should seek to improve on the limitations of the study and look back after the significant part of the crisis is over. Thus, additional information about CSR activities could be added after the crisis. Looking back in time, future research could test the relationships between different CSR practices during the coronavirus crisis and their influence on the ability of firms to improve image, improve financial performance, leverage innovation to update product portfolio, and overall impact on the firm. Additionally, future researchers may test whether the leverage of core competencies in creating CSR output provides any additional benefits on those dimensions. For example, what was the difference between philanthropy-based CSR and CSR based on core competencies, in terms of impact on image, innovation and growth and financial performance of firms.

\section{Conclusions and Summary}

The coronavirus pandemic has been a formative event impacting our life and way of thinking. Organizations and businesses contributed efforts and resources to cope with the consequences of the pandemic, following the notion of their social responsibility within society. The impact of the various CSR practices will be examined in the future. The sheer scale of CSR, in the face of a major worldwide crisis, provides an opportunity to sharpen our understanding and insights on the best ways that firms should plan and practice their social responsibility.

This article has both practical and theoretical contributions. It provides extensive data about CSR practices through two main perspectives - according to target stakeholders constituencies and according to various dimensions of firms' core competencies. This leads to better understanding on which CSR practices works best in terms of the business and society, as well as serving as a basis for further research examining various aspects of CSR at times of crisis and in the afterwards 'new normal'.

The coronavirus pandemic, although we would have been better off without it, provided an opportunity for deep examination of social responsibility practices. While corporations' efforts were stretched to the limit, the situation served as a magnifying lens examine CSR in its core sense, and not as a 'nice to have' or public relations campaign.

\section{References}

Barney, J. B. (1991). The resource-based view of strategy: Origins, implications, and 
prospects. Journal of Management, 17(1), 97-211.

https://doi.org/10.1177/014920639101700107

Berman, S. L., Wicks, A. C., Kotha, S., \& Jones, T. M. (1999). Does stakeholder orientation matter? The relationship between stakeholder management models and firm financial performance. Academy of Management Journal, 42, 488-506. https://doi.org/10.5465/256972

Carroll, A. B. (1979). A three-dimensional conceptual model of corporate social performance. Academy of Management Review, 4, 497-506. https://doi.org/10.5465/amr.1979.4498296

Carroll, A. B. (1999). Corporate social responsibility: Evolution of a definitional construct. Business \& Society, 38, 268-295. https://doi.org/10.1177/000765039903800303

Carroll, A. B., \& Shabana, K. M. (2010). Business Case for Corporate Social Responsibility: A Review of Concepts, Research and Practice. International Journal of Management Reviews, 12, 85-105. https://doi.org/10.1111/j.1468-2370.2009.00275.x

Cohen, R. (2012). Five Lessons From the Banana Man. The Wall Street Journal, (June 2-3, 2012), p. C2.

Crane, A., \& Matten, D. (2004). Business ethics: A European perspective. New York: Oxford University Press.

Darus, F., Amran, A., Nejati, M., \& Yusoff, H. (2014). Corporate social responsibility towards the community: evidence from Islamic financial institutions in Malaysia. International Journal of Green Economics, 8(3-4), 273-287. https://doi.org/10.1504/IJGE.2014.067729

Derousseau, R. (2018). Good behavior, heavenly returns. Fortune, 45-47.

DesJardins, J. (2016). Is it time to jump off the sustainability bandwagon? Business Ethics Quarterly, 26(1), 117-135. https://doi.org/10.1017/beq.2016.12

Donaldson T., \& Preston L. E. (1995). The stakeholder theory of the corporation: Concepts, evidence, and implications. Academy of management Review, 20(1), 65-91.

https://doi.org/10.5465/amr.1995.9503271992

Eells, R. S. F., \& Walton, C. C. (1974). Conceptual Foundations of Business. Toronto: Irwin.

Farooq, O., Rupp, B. E., \& Farooq, M. (2017). The multiple pathways through which internal and external corporate social responsibility influence organizational identification and multifoci outcomes: The moderating role of cultural and social orientations," Academy of Management Journal, 60(3), 954-985. https://doi.org/10.5465/amj.2014.0849

Fortune. (2020). [Online] Available: http://fortune.com/2017/06/07/fortune-500-women-ceos/

Freeman, R. E. (1984). Strategic Management: A Stakeholder Approach. Boston: Pitman.

Garriga, E., \& Melé, D. (2004). Corporate social responsibility theories: Mapping the territory. Journal of Business Ethics, 53(1-2), 51-71.

https://doi.org/10.1023/B:BUSI.0000039399.90587.34 
Griffin, J. J., \& Mahon, J. F. (1997). The corporate social performance and corporate financial performance debate. Business \& Society, 36, 5-31.

https://doi.org/10.1177/000765039703600102

Hafenbradl, S., \& Waeger, D. (2017). Ideology and the micro-foundations of CSR: Why executives believe in the business case for CSR and how this affects their CSR engagements. Academy of Management Journal, 60(4), 1582-1606. https://doi.org/10.5465/amj.2014.0691

Hengst, I. A., Jarzabkowski, P., Hoegl, M., \& Muethel, M. (2020). Toward a process theory of making sustainability strategies legitimate in action, Academy of Management Journal, 63(1), 246-271. https://doi.org/10.5465/amj.2016.0960

International Monetary Fund (2020). In Brief. BusinessWeek, 5.

Kotler, P., \& Keller, K. L. (2012). Marketing Management. Harlow; Boston MA: Pearson Education.

Lantos, G. P. (2002). The ethicality of altruistic corporate social responsibility. Journal of Consumer Marketing, 19(3), 205-232. https://doi.org/10.1108/07363760210426049

Lee, M. D. P. (2008). A review of the theories of corporate social responsibility: Its evolutionary path and the road ahead. International Journal of Management Reviews, 10(1), 53-73. https://doi.org/10.1111/j.1468-2370.2007.00226.x

Marom, I. Y. (2006). Toward a unified theory of the CSP-CFP link. Journal of Business Ethics, 67, 191-200. https://doi.org/10.1007/s10551-006-9023-7

McWilliams, A., \& Siegel, D. (2001). Corporate social responsibility: a theory of the firm perspective. Academy of Management Review, 26, 117-127.

https://doi.org/10.5465/amr.2001.4011987

Orlitzky, M., Schmidt, F. L., \& Rynes, S. L. (2003). Corporate social and financial performance: a meta-analysis. Organization Studies, 24, 403-441.

https://doi.org/10.1177/0170840603024003910

Panapanaan, V. M., Linnanen, L., Karvonen, M. M., \& Phan, V. T. (2003). Roadmapping corporate social responsibility in Finnish companies. Journal of Business Ethics, 44(2-3), 133-148. https://doi.org/10.1023/A:1023391530903

Pearce, C. L., Wassenaar, C. L., \& Manz, C. C. (2014). Is shared leadership the key to responsible leadership? Academy of Management Perspectives, 28(3), 275-288.

https://doi.org/10.5465/amp.2014.0017

Mackintosh, J. (2020). The shareholder isn't all that matters? Don't count on it. The Wall Street Journal, $R 4$.

Manz, C. C. (2015). Taking the self-leadership high road: Smooth surface or potholes ahead? Academy of Management Perspectives, 29(1), 132-151.

https://doi.org/10.5465/amp.2013.0060 
Master Class. (2013). Businessweek. p. 83.

https://doi.org/10.3366/edinburgh/9780748641277.003.0004

Nalick, M., Josefy, M., Zardkoohi, A., \& Bierman, L. (2016). Corporate Sociopolitical Involvement: A Reflection of Whose Preferences?. Academy of Management Perspectives, 30(4), 384-403. https://doi.org/10.5465/amp.2015.0033

Nadim, A., \& Lussier, R. N. (2012). Sustainability as a small business competitive strategy, Journal of Small Business Strategy, 21(2), 79-95.

NPR (National Public Radio) (2020). [Online] Available:

https://www.npr.org/2019/06/20/734408574/new-report-says-college-educated-women-will-s oon-make-up-majority-of-u-s-labor-f

O'Keefe, B. (2020). Business faces the climate crisis. Fortune, 46-48.

Porter, M. E., \& Kramer, M. R. (2006). Strategy \& society: The link between competitive advantage and corporate social responsibility. Harvard Business Review, 84, 78-92.

Raffiee, J., \& Byun, H. (2020). Revisiting the portability of performance paradox: employee mobility and the utilization of human and social capital resources, Academy of Management Journal, 63(1), 34-63. https://doi.org/10.5465/amj.2017.0769

Remisova, A., \& Buciova, Z. (2012). Measuring corporate social responsibility towards employees, Journal for East European Management Studies, 17(3), 273-291.

https://doi.org/10.5771/0949-6181-2012-3-273

Roman, R. M., Hayibor, S., \& Agle, B. R. (1999). The relationship between social and financial performance: Repainting a portrait. Business \& Society, 38(1), 109-125.

https://doi.org/10.1177/000765039903800105

Rowley, T., \& Berman, S. (2000). A brand-new brand of corporate social performance. Business \& Society, 39(4), 397-418. https://doi.org/10.1177/000765030003900404

Schaefer, S. (2016). The Just 100: America’s Best Corporate Citizens. Forbes, p. 82.

Schubert, T., \& Tavassoli, S. (2020). Product innovation and educational diversity in top and middle management teams, Academy of Management Journal, 63(1), 272-294.

https://doi.org/10.5465/amj.2017.0741

Sen, S., Kotlarsky, J., \& Budhwar, P. (2020). Extending organizational boundaries through outsourcing: toward a dynamic risk-management capability framework, Academy of Management Perspectives, 34(1), 97-113. https://doi.org/10.5465/amp.2015.0191

The Sustainability Consortium, (2020). Responsible companies are sustaining resources - and at a profit. Fortune, 70 .

Timperley, S. (2008). Corporate Social Responsibility Indexes: Measure for Measure. Unpublished doctoral dissertation, The University of Waikato.

Wartzman, R., \& Tang, K. (2019). Companies' broader mission. The Wall Street Journal, R6. 
Washburn, M., \& Bromiley, P. (2013). Managers and analysts: An examination of mutual influence, Academy of Management Journal, 56(4), 1002-1023.

\section{Media References}

101 Ford Media. [Online] Available: https://media.ford.com/content/fordmedia/fna/us/en/news/2020/03/24/ford-3m-ge-uaw-re spirators-ventilators.html

102 Bloomberg. [Online] Available:

https://www.bloomberg.com/news/articles/2020-04-08/cisco-ceo-tells-staff-jobs-are-safeurges-others-to-avoid-cuts?srnd=technology-vp

103 American Bank Association. [Online] Available: https://www.aba.com/about-us/press-room/industry-response-coronavirus

104 NBC. [Online] Available:

https://www.nbcbayarea.com/news/coronavirus/list-companies-offering-deals-discount-fr eebies-coronavirus/2256595/

105 BBC. [Online] Available: https://www.bbc.com/news/business-51956880

106 Dezeen Media. [Online] Available:

https://www.dezeen.com/2020/03/20/coronavirus-shortage-ventilators-hand-sanitiser-elo n-musk/

107 MarketWatch Media. [Online] Available:

https://www.marketwatch.com/story/these-nine-companies-are-working-on-coronavirus-t reatments-or-vaccines-heres-where-things-stand-2020-03-06

108 CNBC. [Online] Available:

https://www.cnbc.com/2020/03/24/coronavirus-ford-ge-3m-partner-to-make-protective-e quipment-ventilators.html

109 Clinical Trials Arena. [Online] Available:

https://www.clinicaltrialsarena.com/analysis/coronavirus-mers-cov-drugs/

110 International Federation of Pharmaceutical Manufacturers. [Online] Available: https://www.ifpma.org/subtopics/novel-coronavirus-covid-19-industrys-rd-efforts/

111 Reuters. [Online] Available:

https://www.reuters.com/article/us-health-coronavirus-philips/philips-to-ramp-up-produc tion-of-ventilators-in-coronavirus-fight-idUSKBN21912C

112 News Center Maine. [Online] Available:

https://www.newscentermaine.com/article/news/health/coronavirus/maine-businesses-ra mp-up-production-hiring-in-fight-coronavirus/97-3ca3f05b-1f18-4b0b-877f-90069e8bb9 $7 \mathrm{e}$

113 WHOTV. [Online] Available: 
https://whotv.com/news/coronavirus/oskaloosa-company-ramps-up-production-on-key-v entilator-part-to-help-fight-coronavirus/

114 Portland Press Herald. [Online] Available:

https://www.pressherald.com/2020/03/29/brunswick-based-starc-systems-to-ramp-up-pro duction-of-containment-units-amid-coronavirus-battle/\#

115 Syracuse News. [Online] Available:

https://www.syracuse.com/coronavirus/2020/03/welch-allyn-owner-hillrom-ramps-up-m edical-device-production-in-fight-against-coronavirus.html

116 TNW. [Online] Available:

https://thenextweb.com/corona/2020/03/16/what-the-worlds-biggest-tech-companies-aredoing-to-fight-coronavirus/

117 VB. [Online] Available:

https://venturebeat.com/2020/03/24/tech-industry-shifts-dollars-and-manufacturing-to-fi ght-coronavirus/

118 Tech Crunch. [Online] Available:

https://techcrunch.com/2020/03/23/daily-crunch-amazon-apple-microsoft-coronavirus/

119 CNN. [Online] Available:

https://edition.cnn.com/2020/03/19/tech/netflix-internet-overload-eu/index.html

120 Variety. [Online] Available:

https://variety.com/2020/digital/news/amazon-apple-degrading-streaming-video-coronavi rus-1203541271/

121 Business Insider. [Online] Available:

https://www.businessinsider.com/coronavirus-changes-walmart-starbucks-employee-ben efits-2020-3

122 Fortune. [Online] Available:

https://fortune.com/2020/04/13/global-500-companies-coronavirus-response-covid-19-pa ndemic/

123 Business Insider. [Online] Available:

https://www.businessinsider.com/coronavirus-stores-special-hours-elderly-vulnerable-list $-2020-3$

124 Business Insider. [Online] Available:

https://www.businessinsider.com/coronavirus-layoffs-furloughs-hospitality-service-travel -unemployment-2020

125 The Wall Street Journal. [Online] Available:

https://www.wsj.com/articles/nissan-furloughs-about-10-000-workers-in-u-s-because-ofcoronavirus- 11586257760

126 Fortune. [Online] Available: 
https://fortune.com/2020/03/23/amazon-walmart-ebay-price-gougers-coronavirus-supplie s-covid-19/

127 Bloomberg. [Online] Available:

https://www.bloomberg.com/news/features/2020-03-25/3m-doubled-production-of-n95-f ace-masks-to-fight-coronavirus

128 Chemical Engineering. [Online] Available:

https://www.chemengonline.com/cpi-companies-step-up-production-of-crucial-supplies-t o-fight-coronavirus-outbreak/

129 The Motley Fool. [Online] Available: https://www.fool.com/investing/2020/03/18/coronavirus-test-makers-ramp-up-production .aspx

130 Tech Crunch. [Online] Available:

https://techcrunch.com/2020/04/02/scoutbee-coronavirus-supply-chain-support/131

Sourcing Allies. [Online] Available:

https://www.sourcingallies.com/coronavirus-manufacturer-support-service-china

132 Enabling Procurement. [Online] Available:

http://enablingprocurement.com/coronavirus-help/

133 Supply Chain Digital [Online] Available:

https://www.supplychaindigital.com/supply-chain-management/hm-use-supply-chain-hel p-hospitals-combat-coronavirus

134 Calcalist. [Online] Available:

https://www.calcalistech.com/ctech/articles/0,7340,L-3803352,00.html

135 Business Insider. [Online] Available:

https://www.businessinsider.com/coronavirus-companies-donations-helping-people

136 WeForum. [Online] Available:

https://www.weforum.org/agenda/2020/03/how-are-companies-responding-to-the-corona virus-crisis-d15bed6137/

137 Coca-Cola. [Online] Available:

https://www.coca-colacompany.com/news/how-the-coca-cola-company-is-responding-tothe-coronavirus-outbreak

138 USA Today [Online] Available:

https://www.usatoday.com/story/tech/reviewedcom/2020/04/07/20-retailers-giving-backduring-coronavirus-pandemic/2963887001/

139 NBC News. [Online] Available:

https://www.nbcnews.com/shopping/lifestyle/brands-donate-coronavirus-relief-n1177806

140 Bloomberg. [Online] Available:

https://www.bloomberg.com/news/articles/2020-03-17/shareholder-meetings-are-going-o 
nline-due-to-the-coronaviru

141 The Wall Street Journal. [Online] Available:

https://www.wsj.com/articles/companies-move-shareholder-meetings-online-amid-coron avirus-lockdown-11586856603

142 WIPFLI. [Online] Available:

https://www.wipfli.com/insights/articles/covid-sec-guidance-on-virtual-shareholder-meet ings-due-to-coronavirus

143 U.S. Securities and Exchange Commission (SEC) [Online] Available:

https://www.sec.gov/news/press-release/2020-62

144 Business Insider. [Online] Available:

https://markets.businessinsider.com/news/stocks/coronavirus-outbreak-stock-guidance-o utlook-cuts-microsoft-apple-mastercard-companies-2020-2-1028947433

145 CNBC. [Online] Available:

https://www.cnbc.com/2020/03/11/coronavirus-at-least-150-companies-have-warned-inv estors.html

146 CNBC [Online] Available: https://www.cnbc.com/2020/03/27/coronavirus-surveillance-used-by-governments-to-fig ht-pandemic-privacy-concerns.html

147. Harvard Business Review. [Online] Available:

https://hbr.org/2020/03/coronavirus-is-a-wake-up-call-for-supply-chain-management

148. Wharton. [Online] Available:

https://knowledge.wharton.upenn.edu/article/veeraraghavan-supply-chain/

149. World Economic Forum. [Online] Available:

https://www.weforum.org/agenda/2020/03/covid-19-coronavirus-lessons-past-supply-cha in-disruptions/

150 BBC. [Online] Available: https://www.bbc.com/news/science-environment-51944780

151 NAA. [Online] Available:

https://www.space.com/nasa-satellite-air-pollution-us-northeast-coronavirus.html

152 World Health Organization. [Online] Available:

https://www.who.int/dg/speeches/detail/who-director-general-s-opening-remarks-at-themedia-briefing-on-covid-19---11-march-2020

153 Johns Hopkins University. [Online] Available: https://gisanddata.maps.arcgis.com/apps/opsdashboard/index.html\#/bda7594740fd40299 423467b48e9ecf6

154 World Health Organization. [Online] Available: https://www.who.int/emergencies/diseases/novel-coronavirus-2019/advice-for-public 
155 ABC News. [Online] Available:

https://abcnews.go.com/Health/middle-coronavirus-crisis-hospitals-fear-financial-ruin/st ory? $\mathrm{id}=69843523$

156 NY Post. [Online] Available:

https://nypost.com/2020/04/01/a-look-inside-an-nyc-hospital-amid-the-coronavirus-crisis

157 We Forum. [Online] Available:

https://www.weforum.org/agenda/2019/03/water-scarcity-one-of-the-greatest-challengesof-our-time

158 Time. [Online] Available:

https://time.com/5819235/apple-google-smartphone-tracking-coronavirus/

\section{Copyright Disclaimer}

Copyright for this article is retained by the author(s), with first publication rights granted to the journal.

This is an open-access article distributed under the terms and conditions of the Creative Commons Attribution license (http://creativecommons.org/licenses/by/4.0/). 